\title{
sciendo
}

\section{Financial Stability of Insurance Companies in Selected CEE Countries}

\author{
Tomislava Pavić Kramarić, Marko Miletić, Renata Kožul Blaževski \\ University of Split, University Department of Professional Studies, Split, Croatia
}

\section{Abstract}

Background: Financial stability or soundness of insurance companies has gained importance over the years, especially after the financial crisis of 2008 . Various stakeholders such as policy makers, regulators, the insured, etc. are interested in keeping the insurance sector stable since it contributes to overall financial stability. Objectives: The authors explore the determinants of insurers' soundness in selected countries in Central and Eastern Europe. The analysis covers life, non-life and composite insurers that operated in Croatia, Hungary, and Poland in the period 2013 - 2017. Methods/Approach: A set of insurer - specific, industry - specific and macroeconomic variables are taken into consideration for having a potential influence on soundness measured by the Z-score. The variables include the size based on total assets, the share of premium ceded to reinsurance, claims growth, gross written premium growth, the premium to surplus ratio, market shares held by the five largest insurers, the share of gross written premium in the gross domestic product (GDP) and the GDP per capita growth. Results: The findings reveal that soundness of Croatian insurers is positively influenced by the size of an insurer. Both in Hungary and Poland reinsurance plays an important factor positively affecting soundness. Conclusions: Each of the insurance markets covered by the analysis reveals its characteristics and offers guidelines on factors influencing financial stability.

Keywords: insurance companies, soundness, Central and Eastern European countries JEL classification: G22, L25, L22

Paper type: Research article

Received: Mar 22, 2019

Accepted: Jun 05, 2019

Citation: Pavić Kramarić, T., Miletić, M., Kožul Blaževski, R. (2019), "Financial Stability of Insurance Companies in Selected CEE Countries", Business Systems Research, Vol. 10, No. 2, pp. 163-178. DOI: 10.2478/bsri-2019-025

\section{Introduction}

The 2008 financial crisis stressed the importance of evaluating the soundness of financial institutions, including insurance companies. This has become the focal point of policy makers and regulators by introducing regulations that are more stringent. Investigating the determinants of insurers' soundness motives behind the crisis can be explained as well and avoided in the future. Besides policy makers and regulators, the sound and stable insurance system are of significant importance to the insured as well, as the benefits that are to be paid depend on the financial well-being of the insurer. Moreover, as stated by Rubio-Misas et al. (2017, p. 272 and 273) „,insurer solvency not only protects policyholders by ensuring that the insurer will be able to meet its financial 
obligations in the future but also contributes to the stability of the financial system". Insurance is significant and growing segment of the financial sector, however, Das et al. $(2003$, p. 3) note that ,its failure can cause a significant and costly disruption, but it is unlikely to lead to financial instability". They also add "insurance companies are not necessarily immune to crises, particularly when they assimilate banking-type activities and/or have a close business relationship with banks, including cross-shareholding, placement of deposits, and credit risk transfers". Rubio-Misas et al. (2017, p. 274) citing Klein (2014) also confirm that "regulators are interested in limiting excessive insolvency risk to avoid a potential problem of contagion to other insurers... and the negative externalities that could arise if the costs of unpaid claims are shifted beyond policyholders to their creditors".

Therefore, the authors wanted to find out what determines soundness in the insurance markets in Croatia, Hungary, and Poland. The authors employ firm-level, industry-level as well as macroeconomic variables to test their effect on the financial stability of insurance companies in these countries. Specifically, variables size of the insurer, share of premium ceded to reinsurance, claims growth, gross written premium growth, premium to surplus ratio, market shares held by the five largest insurers, share of gross written premium in GDP as well as GDP per capita growth are used as independent variables while their potential influence is explained in part relating to description of variables. Moreover, the dependent variable is a measure of insurance soundness expressed by the Z-score. To sum it up, the authors wanted to find out how this set of variables influence the soundness of insurers in selected CEE countries, assuming the differences in their industry and macroeconomic environment. The analysis is conducted for the period 2013 - 2017. Insurance companies operating in Croatia, Hungary, and Poland are chosen for the analysis assuming that there are common features affecting insurer's soundness in these countries. Moreover, they belong to the group of Central and Eastern European countries having a similar insurance market level of development (Table 1).

Table 1

Level of Development of Insurance Markets in 2017

\begin{tabular}{lll}
\hline Country/Indicator & Total premium per inhabitant & Total premium to GDP (\%) \\
\hline Croatia & $293 €$ & 2.5 \\
Hungary & $314 €$ & 2.5 \\
Poland & $380 €$ & 3.1 \\
\hline
\end{tabular}

Source: Insurance Europe (N/A)

Furthermore, Central and Eastern European countries were chosen due to the fact that research on financial soundness in the insurance sector relating to emerging and developing economies is non-existent. The insurance markets of these countries also share a similar background relating to the transition to a market economy. As stated by Tipurić et al. (2008, p. 97 and 98), insurance companies in these countries "were owned by the state, and most frequently the state provided insurance services through a single insurance company which had a complete monopoly". The same authors also point that "supply of insurance products was scarce, and premium was dominated by non-life insurance, mainly compulsory types of insurance, whereas incentives for the development of life insurance were almost nonexistent." The insurance markets have evolved since then in terms of the increased number of insurance companies, especially in foreign ownership, products offered, a number of the insured, the volume of gross written premium, adoption of EU regulations, etc. All these changes have brought certain risks making this research topic relevant. 
The paper contributes to the existing literature in a number of ways. Firstly, it adds to the generally scarce empirical research on soundness in the insurance sector by providing new evidence on the issue. Moreover, it is the first research of its kind exploring soundness on the cross-country level relating to Central and Eastern European countries. Since this study deals with emerging insurance markets, it also contributes to the scientific literature on this topic, which mostly covers developed countries. The remainder of the paper is structured as follows. The next section gives a review of the prior empirical research pertaining to the topic investigated. The third section describes the variables used in the study as well as their expected influence on soundness. Empirical framework, as well as empirical results, are provided in section four. The final section contains a brief summary and concludes.

\section{Literature Review}

Despite the relevance and importance of the investigated issue, the determinants of soundness have not been extensively explored in the insurance sector as opposed to, for example, the banking sector. However, the findings of several papers dealing with the topic are given as follows.

Chen et al. (2004) investigate the determinants of the financial health of Asian insurance companies. Their paper is oriented on the solvency of insurance companies that operated in Japan, Malaysia, Taiwan, and Singapore. The authors distinguish factors that might influence property-liability insurers' and those that might affect life insurers' financial stability. The factors that the authors consider important in determining property-liability insurers' financial health comprise of firm size, investment performance, operating margin, premium growth, surplus growth, combined ratio and liquidity whereas firm size, investment performance, operating margin, change in asset mix, change in product mix and insurance leverage are used in the model relating to life insurers. Furthermore, the authors have also employed market and economic factors relating to both property-liability and life/health insurers, including a number of insurers, changes of interest rate, the absolute level of interest rate, and inflation rate. The authors conduct logistic regressions for the period 1 year and 2 years prior to prediction. They find that the factors significantly affecting property-liability insurers' financial health are firm size, investment performance, liquidity ratio, surplus growth, combined ratio, and operating margin. Furthermore, the factors that have statistically significant impact on life insurers' financial health are firm size, change in asset mix, investment performance, and change in product mix with the last three features relating to Japan.

Shim (2011) explores M\&A activities, product diversification, and financial performance in the U. S. property-liability insurance industry in the period $1989-2004$. The author uses the risk-adjusted ROA, ROE, and Z-score as performance measures. Furthermore, M\&A indicator, as well as product diversification measures, are included in the model together with controls consisting of size based on assets, the ratio of equity capital to total assets, stock investments, geographical diversity index, distribution systems, organizational form dummy, firm structure dummy, and M\&A year dummies. The main findings when performance is measured with Z-score are that M\&A have a negative impact on the insurer's financial performance, two, three, and four years after the said activity has occurred. The same holds for product diversification, square of the natural logarithm of assets and mixed distribution whereas the share of commercial line, natural logarithm of assets, equity capital to total assets ratio, brokerage, mutual and unaffiliated single firms positively affect Z-score.

Pasiouras et al. (2013) investigate the relationship between insurers' soundness and insurance regulatory policies since the recent financial crisis poses challenges to policy 
makers for improving the regulatory framework in order to supervise better the soundness of the insurance sector. The authors use an international dataset of more than 1700 insurers from 46 countries while the regulatory variables consist of capital requirements index, supervisory power index, technical provisions index, investments index and corporate governance and internal control index. Control variables that authors employ in the analysis comprise group structure dummy, business activity dummy, organizational form dummy, size based on assets, real GDP per capita growth, annual inflation rate, share of insurance premium in GDP, economic freedom, overall institutional development and economic development measured as natural logarithm of real GDP per capita. They find that the supervisory power of the authorities, as well as regulations related to both technical provisions and investments, have an impact on soundness.

Shim (2015) investigates whether the market concentration is related to an insurers' financial stability in the U.S. property-liability insurance industry over the period 1992 2010. The author employs two-stage least squares techniques with HerfindahlHirschman index as well as with concentration ratio as explanatory variables used as a measure of concentration. The author also uses several control variables such as firm size, exposure to catastrophe losses, leverage, product diversification, geographic diversification, homeowners line share, the share of the investment portfolio invested in bonds, reinsurance ratio, asset growth, organizational form dummy, group or unaffiliated insurer dummy and interest rate change. The findings show that higher market concentration is related to the lower financial stability of insurers. Furthermore, firm-specific factors including firm size, underwriting leverage, organizational form, product, and geographical diversification as well as the exposure to catastrophes and macroeconomic conditions are important determinants of a safe and stable insurance system.

Cummins et al. (2017) explore the association between life insurers' soundness and competition measured with the Boone indicator. The analysis relates to the period from 1999 to 2011 , covering the sample of ten EU countries, including Austria, Belgium, Denmark, France, Germany, Italy, Netherlands, Spain, Sweden, and the United Kingdom. The goal of the paper is to understand how competition has changed in light of the deregulation process as well as to test the relationship between competition and soundness in the European life insurance market. When investigating the influence of competition on insurers' soundness, the authors employ a set of firmspecific, industry-specific and macroeconomic variables comprising firm size based on assets, group dummy, share of reinsurance, invested assets to total assets ratio, net premium to equity ratio, market size, inflation rate, five firm concentration ratio, share of life insurance premium in GDP, real GDP growth and financial crisis dummy. The authors find that competition reallocates profits from inefficient to efficient insurers. Furthermore, competition enhances the soundness of the EU life insurance markets though the soundness-enhancing effect of the competition is greater for weak insurers than for healthy ones.

\section{Methodology}

\section{Variables description}

The authors are investigating the determinants of insurance companies' soundness which is presented with Z-score, a measure used in empirical literature relating to insurance segment (e.g., Shim, 2011; Pasiouras et al., 2013; Shim 2015; Cummins et al., 2017). Z-score as a measure of financial soundness or stability is exploited in empirical 
research relating to the banking sector as well (e.g., Laeven et al., 2009; DemirgüçKunt et al., 2010; Demirgüç-Kunt et al., 201 1; Bourkhis et al., 2013; Schaeck et al., 2014).

The rationale for using Z-score as a measure of financial stability can be found in Cummins et al. (2017), citing Shim (2011) and Pasiouras et al. (2013), stating that equity serves as a buffer against unforeseen losses and is critical to an insurer's ability to meet its obligations. Moreover, Z-score is a measure of distance to default that is contrariwise related to the likelihood of insolvency.

The soundness of an insurance company as a dependent variable is presented with Z-score using the following expression:

$$
Z_{i, t}=\frac{R O A_{i, t}+E / A_{i, t}}{\sigma_{R O A i, t}}
$$

where ROA is a measure of profitability calculated as net profit after taxes to total assets ratio, E/A is a measure of capitalization, i.e., equity to assets ratio and $\sigma R O A$ represents the return volatility expressed by the standard deviation of ROA.

When calculating oROA, we have followed Cummins et al. (2017) and Schaeck et al. (2014) approach using a three-year rolling window to allow for variation in the denominator of the Z-score. This is also done to avoid Z-score being solely driven by the variation in the level of ROA and E/A. In other words, in order to calculate Z-score in 2013, we have used data from 2011 to 2013. It is worth mentioning that Shim (2015) has calculated the standard deviation of ROA by using 5-year rolling periods of data. Moreover, in order to control for non-linear effects and outliers, the authors have used the logarithm of Z-score as Cummins et al. (2017) and Pasiouras et al. (2013).

Since the soundness of insurance companies is determined by various factors, the authors have employed different firm-level, industry-level, and macroeconomic variables in order to capture important aspects of insurance companies and insurance markets activities. Specifically, insurance company - specific variables used in the research comprise of the size of an insurer, share of premium ceded to reinsurance, claims growth, gross written premium growth and premium to surplus ratio, while industry-level variable consists of market shares held the five largest insurers. At the country level, the authors have also employed share of gross written premium in GDP and, in order to capture the feature of the macroeconomic environment, GDP per capita growth. Description of each of these variables, including the way of their calculation and potential impact on the dependent variable, is given as follows.

Size variable (In_size) calculated as natural logarithm of total assets is widely used in empirical research relating to determinants of firm soundness in both insurance industry (e.g. Shim, 2011; Pasiouras et al., 2013; Shim, 2015; Cummins et al. 2017) as well as to banking sector (e.g. Demirgüç-Kunt et al. 2006; Laeven et al., 2009). Cummins et al. (1995) as well as Cummins et al. (1999) have used the size variable calculated as natural logarithm of total assets in in (solvency) prediction in the insurance sector while Yanase et al. (2008) have used it when investigating risk taking behaviour in the Japanese life insurance industry. Moreover, it is also used as a control variable when investigating profitability determinants of insurers (e.g., Adams et al., 2003; O'Sullivan et al., 2003; Weiss et al., 2008). Therefore, the authors have employed this variable in order to control for differences in size, since, as stated by Chen et al. (2004), the financial health of any business entity is under the influence of, among other factors, the size or total assets of the firm. The same authors note that as regulators are less likely to liquidate larger insurance companies, it is expected that small insurers are more vulnerable to insolvency. Moreover, Shiu (2004) underlines that large insurance 
firms generally have a greater ability for dealing with adverse market oscillations and can recruit capable workforces with professional knowledge rather easily resulting in better performance. On the other hand, Pi et al. (1993) highlight that financial performance of the firm might be inversely related to size since it is frequently difficult for owners to efficiently and effectively supervise managers as the firm develops. Furthermore, the diseconomies of scale should also be taken into account. Shim (2011) find the size of the insurance company to positively affect performance measured with Z-score, while Cummins et al. (2017) find its negative influence on performance. Furthermore, Pasiouras et al. (2013), in six different regressions find size variable to be positively and negatively associated with insurers' soundness, depending on the regulatory index used in the model. Therefore, the influence of the size variable on soundness is uncertain.

Reinsurance ratio (RE) is another control variable often employed in empirical research, and it represents premium ceded to reinsurance to total gross written premium ratio. According to Shim (2015), the use of reinsurance can improve the insurer's underwriting capacity to write new business and enable an insurer to hold less capital without increasing the likelihood of its failure. Moreover, Cummins et al. (2008) also state that reinsurance increases the financial viability of insurers. Therefore, the positive influence of reinsurance on soundness might be expected. Contrary to the expectations, empirical findings by Shim (2015) show that insurers with more reinsurance are not financially more stable implying that insurance companies with higher use of reinsurance are more likely to have a limitation on their capacity for bearing additional risk and demonstration a high-risk exposure. Cole et al. (2006) also find that less profitable firms demand more reinsurance. Furthermore, Rubio-Misas et al. (2017), when investigating the factors influencing the level of the regulatory solvency ratio, find the reinsurance use to be negative. It is also worth noting that Kim et al. (1995) while examining the insurers' insolvencies, find in one model that the more the insurer is exposed to reinsurance, the more it is exposed to the undesirable financial impact of reinsurer insolvency. To sum it up, the influence of reinsurance utilization on soundness is ambiguous.

Claims growth (claims_growth) is calculated as follows:

$$
\frac{\text { NetClaimsIncurred }_{t}-\text { NetClaimsIncurred }_{t-1}}{\text { NetClaimsIncurred }_{t-1}} \cdot 100
$$

where net claims incurred $d_{t}$ represents net claims incurred in the current year $t$ and net claims, incurredt-1 stands for net claims incurred in the previous year. It has been extensively used in empirical literature dealing with determinants of insurers' profitability. Since profitability expressed with ROA is a component of soundness, the authors predict its influence on insurers' stability or soundness as well. Specifically, as an increase in claims reduces technical result and consequently profits, we expect its negative influence. Hoerger et al. (1990) state that higher loss volatility is expected to affect the probability of bankruptcy.

Gross written premium growth (GWP_growth), according to Chen et al. (2004) measures the rate of market penetration. It is calculated as a percentage change in the gross written premium of each insurer in each year, i.e., as:

$$
\frac{G W P_{t}-G W P_{t-1}}{G W P_{t-1}} \cdot 100
$$


In the paper investigating the determinants of the financial health of Asian insurance companies, Chen et al. (2004) note that being excessively focused on growth can lead to self-destruction since other important goals might be ignored. Furthermore, findings by Kim et al. (1995) support the thesis that the rapid growth of premiums is one of the factors contributing to insolvency. Extensive premium growth increases underwriting risk as well as technical provisions, consequently having an adverse effect on profitability. Therefore, the negative influence of this variable on soundness is expected.

In order to measure the capacity of an insurer to underwrite new insurance policies premium to surplus ratio (prem_surplus) variable is employed in the analysis as well. As stated by Cummins et al. (1995), it is regularly used a measure of underwriting risk and leverage. Besides Cummins et al. (1995) using this measure when investigating insolvency in property-liability insurance, other authors such as Shim (2015) and Cummins et al. (2017) have also employed this variable as a potential factor influencing insurers' soundness or stability. It is calculated as the net premiums written to equity, i.e., surplus representing an insurance leverage ratio. We expect that premium to surplus is negatively related to soundness. As stated by Shim (2015), an insurer should have adequate policyholders' surplus if it plans to increase its premium volume. Therefore, a low premium to equity ratio is considered a sign of financial strength.

Market share held by the five largest insurance companies (MS5), or five-firm concentration ratio, is calculated as the sum of market shares by the five largest insurers based on gross written premium. As stated by Cummins et al. (2017), it is employed in the model in order to control for the effect of market structure. Moreover, Shim (2015) emphasizes the importance of the relationship between changes in market concentration and financial stability of insurance companies for policy-makers who develop policies about industry structure, including M\&A guidelines and market competitiveness. The same author explains two conflicting streams about the relationship between market concentration and financial stability in the literature. The one group represents the view that large companies operating in very concentrated markets are likely to earn more profits implementing the market power that is proved in the research by, e.g. Beck et al. (2006) and Cummins et al. (2017). On the other hand, authors such as Uhde and Heimeshoff (2009) and Shim (2015) prove that a more concentrated market structure with a few large firms is more susceptible to financial fragility than a less concentrated market system. Therefore, the influence of this variable is ambiguous.

Gross written premium in GDP (GWP_in_GDP) is used to control for the level of insurance activity in the country where an insurer is domiciled following Cummins et al. (2017) approach. Share of gross written premium in GDP is also used by Pasiouras et al. (2013) as a proxy for the overall development in the insurance industry. We expect that more developed insurance sector will positively influence the soundness of insurers.

GDP per capita growth (GDP_pc_growth) is also employed in the model since it reflects features of the macroeconomic environment and the level of development of the insurance industry. As stated by Pasiouras et al. (2013) citing Demirgüç-Kunt et al. (1998), problems in the financial sector are more likely to occur when the growth is low. Therefore, we predict the positive influence of this variable on soundness. The statistically significant and positive impact of this variable on soundness is also found by Demirgüç-Kunt et al. (2006) in the banking industry and Cummins et al. (2017) in the insurance industry. 


\section{Data}

Our sample consists of the registered insurance companies (including life, non-life, and composite insurers) that operated in the insurance markets in the countries chosen for the analysis in the period from 2013 to 2017. Specifically, in the Croatian and Hungarian insurance markets, there are life, non-life and composite insurance companies operating in the market whereas in the Polish insurance market there are companies conducting exclusively life and companies conducting exclusively nonlife insurance business. Those insurers that have not been operating in each year of the observed period for various reasons such as mergers and acquisitions or started operating in later years covered by the analysis were omitted from the analysis. Furthermore, it refers to domestic activities only whereas reinsurance companies were not included in the analysis.

Since we deal with cross-country research, multiple sources were used in order to collect data and calculate all insurance company - level and insurance industry level variables used in this study.

Specifically, regarding the Croatian insurance market, the data on total assets, total gross written premium and net profit after taxes were obtained from regular publications published by Croatian Financial Services Supervisory Agency (HANFA), a supervisory body whose scope of activities and competence cover the supervision of financial markets, financial services and supervised entities providing those services including insurance companies. Furthermore, data on claims, net premiums, premiums ceded to reinsurance and equity capital were manually collected form insurers' annual reports publicly available through Croatian Financial Agency (FINA), a public company providing financial and electronic services including financial mediation, cash operations, business information, e-business, archiving, electronic signature authorization, education, payment transactions etc. Finally, our research sample relating to Croatian insurance market consists of 19 companies per year, making a total of $98 \%$ of the market in 2017 or 95 observations.

Regarding the Hungarian insurance market, data for all variables were taken from publications called Golden Books including individual data of supervised institutions published on web pages of Hungarian Central Bank (Magyar Nemzeti Bank) (N/A). The final research sample relating to Hungarian insurance market comprised 22 insurers per year, making a total of $87.6 \%$ of the market in 2017 or 110 observations.

Data necessary for the calculation of variables in the Polish insurance market were taken from the Polish Insurance Association (PIU) (N/A). Specifically, various issues of publication named Statistics were used in order to calculate all firm-specific variables as well as the market share of the five largest insurers. Lastly, the final sample regarding the Polish insurance market consists of 36 life and non-life insurance making a total of 180 observations. In 2017, these companies made $77.5 \%$ share of the total insurance market.

At the country level, we have included control variable for the main macroeconomic conditions which is GDP per capita growth obtained from World Bank national accounts data and OECD National Accounts data files (World Bank, N/Aa; N/Ab; N/Ac).

Moreover, variable gross written premium in GDP for each country covered by the analysis is obtained from the Insurance Europe Industry Database relating to Total Insurance. 


\section{Results}

Descriptive statistics for all variables employed are provided in Table 2 separately for each country covered by the analysis. These are computed based on the 95, 110 and 180 observation recorded in Croatia, Hungary, and Poland respectively.

Table 2

Descriptive Statistics of Variables by Country

\begin{tabular}{|c|c|c|c|c|c|c|}
\hline \multicolumn{2}{|c|}{ Country/Variable } & Obs & Mean & Std. dev. & Min & Max \\
\hline \multirow{10}{*}{$\begin{array}{l}\frac{\sigma}{\frac{0}{0}} \\
\frac{0}{U}\end{array}$} & Z-score & 95 & 134.36 & 338.28 & 2.23 & 2287.12 \\
\hline & In_size & 95 & 20.40 & 1.66 & 17.52 & 23.00 \\
\hline & RE & 95 & 10.16 & 12.72 & 0 & 59.01 \\
\hline & claims_growth & 95 & 120.42 & 705.69 & -98.73 & 6682.18 \\
\hline & GWP_growth & 95 & 1.64 & 1.64 & -0.50 & 3.50 \\
\hline & prem_surplus & 95 & 92.12 & 59.29 & 0.14 & 247.54 \\
\hline & MS5 & 95 & 0.64 & 0.01 & 0.62 & 0.66 \\
\hline & GWP_in_GDP & 95 & 2.60 & 0.11 & 2.50 & 2.80 \\
\hline & GDP_pc_growth & 95 & 2.35 & 1.93 & -0.21 & 4.26 \\
\hline & In_Z-score & 95 & 3.88 & 1.32 & 0.80 & 7.74 \\
\hline \multirow{8}{*}{$\begin{array}{l}\text { 처 } \\
\text { 온 } \\
\text { ํㅗ }\end{array}$} & Z-score & 110 & 58.70 & 75.49 & 2.11 & 429.10 \\
\hline & In_size & 110 & 17.34 & 1.60 & 14.45 & 19.57 \\
\hline & RE & 110 & 20.77 & 22.12 & -0.21 & 81.81 \\
\hline & claims_growth & 110 & 4.71 & 62.15 & -467.78 & 278.11 \\
\hline & GWP_growth & 110 & 10.25 & 20.87 & -50.83 & 95.42 \\
\hline & prem_surplus & 110 & 2.92 & 2.47 & 0.14 & 11.56 \\
\hline & MS5 & 109 & 61.20 & 1.43 & 59.40 & 63.31 \\
\hline & GWP_in_GDP & 110 & 2.56 & 0.04 & 2.49 & 2.62 \\
\hline \multirow{12}{*}{$\begin{array}{l}\text { 으 } \\
\text { 흥 }\end{array}$} & GDP_pc_growth & 110 & 3.47 & 0.89 & 2.38 & 4.51 \\
\hline & In_Z-score & 110 & 3.45 & 1.17 & 0.75 & 6.06 \\
\hline & Z-score & 180 & 60.20 & 171.43 & 1.41 & $2,204.39$ \\
\hline & In_size & 180 & 13.65 & 1.92 & 9.50 & 17.56 \\
\hline & $\mathrm{RE}$ & 180 & 12.97 & 19.27 & -0.01 & 82.35 \\
\hline & claims_growth & 180 & 8.33 & 161.00 & $-1,829.22$ & 861.97 \\
\hline & GWP_growth & 180 & 5.22 & 30.04 & -69.20 & 172.39 \\
\hline & prem_surplus & 180 & 322.44 & $1,192.56$ & 0.00 & $12,319.89$ \\
\hline & MS5 & 180 & 49.03 & 3.40 & 45.23 & 54.40 \\
\hline & GWP_in_GDP & 180 & 2.86 & 0.44 & 2.00 & 3.20 \\
\hline & GDP_pc_growth & 180 & 3.33 & 1.10 & 1.45 & 4.79 \\
\hline & In_Z-score & 180 & 3.40 & 1.05 & 0.34 & 7.70 \\
\hline
\end{tabular}

Source: Authors' work

Before creating panel data models, it is necessary to check the problem of multicollinearity between independent variables. With this aim, the matrix of Pearson correlation coefficients is computed that is due to the space considerations provided in Appendices A-C. An absolute value of the Pearson coefficient higher than 0.7 indicates a strong correlation, which can be identified in Croatia between variable gwp_growth with variables MS5, GWP_in_GDP, and GDP_pc_growth. Moreover, the problem of multicollinearity is present between variables MS5 and GDP_pc_growth as well as between variables GWP_in_GDP and GDP_pc_growth. When observing variables from the Hungarian insurance market problem of multicollinearity is identified between variables MS5 and GWP_in_GDP. In Poland, the problem of multicollinearity is identified between variables MS5 and GDP_pc_growth and between variables GWP_in_GDP and GDP_pc_growth. Since this can affect the final findings of the models, the variables gwp_growth, MS5, and GWP_in_GDP have been omitted from 
the model relating to Croatia. Furthermore, variable MS5 has been eliminated from the model relating to the Hungarian insurance market while variable GDP_pc_growth has been omitted to form the sample relating to the Polish insurance market.

Before the panel analysis was conducted, the stationarity in a panel dataset was tested. A Fisher-type unit-root test based on an augmented Dickey-Fuller test was implemented. The presence of unit roots was tested in all variables. The results for the variables In_size, RE, and GDP_pc_growth for Croatian market showed that these variables are not stationary. Variables InZ and In_size in the Hungarian market were not stationary while in the Polish market, variable MS5 was not stationary. After finding the first difference for these variables, the same unit-root test was conducted, and the result showed that the first differences of these variables were stationary. After that, differenced variables were used in research. The results of a Fisher-type unit-root test based on an augmented Dickey-Fuller are provided in Appendices D-F.

Breusch-Pagan test was used to test for heteroscedasticity in each model. In the Breusch-Pagan test, the null hypothesis assumes homoscedasticity is present. If the heteroscedasticity is present, the standard errors are biased, which can lead to bias in test statistics and confidence intervals. Table 3 presents the results of the BreuschPagan test for models used on each insurance market. As can be seen from Table 3 , there is no problem of heteroscedasticity in none of the models.

Table 3

Results of the Breusch-Pagan Tests for Heteroscedasticity by Country

\begin{tabular}{lllllll}
\hline Tests & Croatia & & Hungary & & Poland & \\
\hline & chi2 & p value & chi2 & p value & chi2 & p value \\
Breusch-Pagan test & 0.14 & 0.7111 & 0.80 & 0.3723 & 0.05 & 0.8208 \\
\hline Source: Authors'w & & & & & &
\end{tabular}

Source: Authors' work

Furthermore, all the variables were systematized in a balanced panel database, which was analysed by applying models with fixed effects and with random effects. The Hausman test was performed to investigate which static panel model is most appropriate. A result showed that a model with random effects is more suitable than the model with fixed effects for all insurance markets covered by the analysis. The empirical results for models on three different insurance markets are presented in Table 4, while their interpretation follows below.

As presented by Table 4, the results of the analysis reveal factors influencing the soundness of insurance companies in different CEE insurance markets. Specifically, statistically significant features influencing soundness in the Croatian insurance market is the size of the insurer based on total assets. A positive sign of size variable suggests that larger insurance companies are likely to be more stable and sounder. The same is found by Chen and Wong (2004), Shim (2011), Pasiouras et al. (2013) and Shim (2015). On the other hand, the opposite is found by Cummins et al. (2017).

Furthermore, the only variable having a significant impact on Hungarian as well as on Polish insurers' soundness is a share of reinsurance. Its positive influence on insurers' soundness is supported by the views of Shim (2015) and Cummins et al. (2008). Specifically, Cummins et al. (2008, p. 6) state that "reinsurance reduces insurers' insolvency risk by stabilizing loss experience, increasing capacity, limiting liability on specific risks, and/or protecting against catastrophes." Furthermore, Berger et al. (1992, p. 253) note that "reinsurance is an important mechanism for risk diversification in insurance markets since it protects the insurer against catastrophic losses and possible insolvency".

Table 4 
Parameter Estimates of Static Panel Model

\begin{tabular}{|c|c|c|c|}
\hline Variable & Croatia & Hungary & Poland \\
\hline In_size & $\begin{array}{l}0.3649075^{* *} \\
(0.1638495)\end{array}$ & $\begin{array}{l}0.6068781 \\
(0770661)\end{array}$ & $\begin{array}{l}0.1074867 \\
(0.3130879)\end{array}$ \\
\hline RE & $\begin{array}{l}-0.000005 \\
(0.0001063)\end{array}$ & $\begin{array}{l}0.0072696^{*} \\
(0.0041656)\end{array}$ & $\begin{array}{l}0.0260577^{*} \\
(0.0140236)\end{array}$ \\
\hline claims_growth & $\begin{array}{l}-0.0000643 \\
(0.0001225)\end{array}$ & $\begin{array}{l}0.0015588 \\
(0.0013754)\end{array}$ & $\begin{array}{l}0.0001908 \\
(0.0008048)\end{array}$ \\
\hline GWP_growth & - & $\begin{array}{l}-0.0034333 \\
(0.0048579)\end{array}$ & $\begin{array}{l}-0.0025614 \\
(0.0024476)\end{array}$ \\
\hline prem_surplus & $\begin{array}{l}-0.001963 \\
(0.0028116)\end{array}$ & $\begin{array}{l}0.0012992 \\
(0.0384824)\end{array}$ & $\begin{array}{l}-0.0000795 \\
(0.000161)\end{array}$ \\
\hline MS5 & - & - & $\begin{array}{l}-0.0309074 \\
(0.0943634)\end{array}$ \\
\hline GWP_in_GDP & - & $\begin{array}{l}-0.5495953 \\
(1.962576)\end{array}$ & $\begin{array}{l}-1.064012 \\
(1.014082)\end{array}$ \\
\hline GDP_pc_growth & $\begin{array}{l}0.0608949 \\
(0.0747921)\end{array}$ & $\begin{array}{l}-0.0146925 \\
(0.1200586)\end{array}$ & - \\
\hline cons & $\begin{array}{l}-3.400061 \\
(3.331478)\end{array}$ & $\begin{array}{l}1.450645 \\
(5.262112)\end{array}$ & $\begin{array}{l}-1.628476 \\
(5.097623)\end{array}$ \\
\hline R2 within & 0.0270 & 0.0728 & 0.0874 \\
\hline R2 between & 0.2121 & 0.0871 & 0.0269 \\
\hline R2 overall & 0.1769 & 0.0586 & 0.0040 \\
\hline Hausman test & $\begin{array}{l}\text { chi }=4.84 \\
p \text { value }=0.4359\end{array}$ & $\begin{array}{l}\text { chi } 3.74 \\
\text { p value }=0.8091\end{array}$ & $\begin{array}{l}\text { chi }=9.90 \\
p \text { value }=0.1287\end{array}$ \\
\hline
\end{tabular}

Source: Authors' work

Note: $* * *, * * *$ Statistically significant at the; $10 \%, 5 \%, 1 \%$ level, respectively. Standard errors are between parentheses.

\section{Conclusion}

Insurance companies are facing constant changes regarding their business activities due to the changes in the insurance sector environment, including regulatory, technological, macroeconomic changes, etc. This puts enormous challenges to regulators, policy-makers, and standard-setting bodies for introducing improved policies and procedures, i.e., regulatory framework. This should all be done in order to ensure safe and stable insurance markets for the benefit and protection of policyholders and to contribute to overall financial stability.

As emphasized by the International Association of Insurance Supervisory (IAIS) (N/A) in Insurance Core Principle 1 (ICP 1), the main aim of insurance supervision is to: "protect policyholders, promote the maintenance of a fair, safe and stable insurance market, and ontribute to financial stability".

In this paper, the authors examine the insurer-specific, industry-specific, and macroeconomic determinants of the financial soundness of insurers in three Central and Eastern European economies.

Empirical results show key determinants in ensuring a stable and safe insurance market. Firstly, firm size based on total assets significantly and positively affects insurer's financial health, suggesting that larger insurers are expected to be financially sounder than small insurers. Moreover, as shown by Hungarian and Polish insurers, those insurance companies that utilize reinsurance more are found to be more stable.

By recognising the insurer-specific factors together with market structure and macroeconomic conditions that might affect insurers' financial soundness, our results 
should offer regulators and policy makers important guidelines about determinants of the insurer's financial health. Specifically, the findings reveal that insufficient size and reinsurance coverage might endanger the financial stability of the insurer. These elements could be used as an early warning system for policy makers, i.e., regulators responsible for insurance sector stability.

Since, each of the insurance markets analysed demonstrates its own features we can cite Chen et al. (2004, p. 495) stating that "insurance regulation is an evolving process and there is a need to be flexible, as there will be continuing changes in the environment and insurance market".

Besides useful insights obtained with this research, the authors are aware of its limitations that should be addressed in future research. Firstly, soundness is a complex variable, and some other aspects might be taken into consideration when examining its determinants such as product diversification, distribution channels, investments in stocks, etc. It might also be useful to explore determinants of insurers' soundness separately for life and non-life insurance segment. Furthermore, adding more countries to the sample covered with the analysis might be worth exploring as well as including pre-crisis and crisis period.

\section{References}

1. Adams, M., Buckle, M. (2003), "The determinants of corporate financial performance in the Bermuda insurance market", Applied Financial Economics, Vol. 13, No. 2, pp. 133-143.

2. Beck, T., Demirgüç-Kunt, A., Levine, R. (2006), "Bank concentration, competition, and crises: First results", Journal of Banking \& Finance, Vol. 30, No. 5, pp. 1581-1603.

3. Berger, L. A., Cummins, J. D., Tennyson, S. (1992), "Reinsurance and the liability insurance crisis", Journal of Risk and Uncertainty, Vol. 5, No. 3, pp.253-272.

4. Bourkhis, K., Nabi, M. S. (2013), "Islamic and conventional banks' soundness during the 20072008 financial crisis", Review of Financial Economics, Vol. 22, No. 2, pp. 68-77.

5. Chen, R., Wong, K. A. (2004), "The determinants of financial health of Asian insurance companies", Journal of Risk and Insurance, Vol. 71, No. 3, pp. 469-499.

6. Cole, C. R., McCullough, K. A. (2006), "A reexamination of the corporate demand for reinsurance", Journal of risk and Insurance, Vol. 73, No. 1, pp. 169-192.

7. Cummins, J. D., Rubio-Misas, M., Vencappa, D. (2017), "Competition, efficiency and soundness in European life insurance markets", Journal of Financial Stability, Vol. 28, pp. 6678.

8. Cummins, J., Dionne, G., Gagné, R., Nouira, A. (2008), "The costs and benefits of reinsurance", available at: https://papers.ssrn.com/sol3/papers.cfm?abstract_id=11422954 (10 December 2018).

9. Cummins, J. D., Grace, M. F., Phillips, R. D. (1999), "Regulatory solvency prediction in property-liability insurance: Risk-based capital, audit ratios, and cash flow simulation", Journal of Risk and Insurance, Vol. 66, No. 3, pp. 417-458.

10. Cummins, J. D., Harrington, S. E., Klein, R. (1995), "Insolvency experience, risk-based capital, and prompt corrective action in property-liability insurance", Journal of Banking \& Finance, Vol. 19, No. 3-4, pp. 511-527.

11. Das, M. U. S., Podpiera, R., Davies, N. (2003), "Insurance and issues in financial soundness", IMF Working Paper 03/138, International Monetary Fund, Washington, DC.

12. Demirgüç-Kunt, A., Detragiache, E. (2011), "Basel Core Principles and bank soundness: Does compliance matter?", Journal of Financial Stability, Vol. 7, No. 4, pp. 179-190.

13. Demirgüç-Kunt, A., Detragiache, E., Tressel, T. (2006), "Banking on the principles: Compliance with Basel Core Principles and bank soundness", The World Bank.

14. Demirgüç-Kunt, A., Huizinga, H. (2010), "Bank activity and funding strategies: The impact on risk and returns", Journal of Financial Economics, Vol. 98, No. 3, pp. 626-650.

15. Hoerger, T. J., Sloan, F. A., Hassan, M. (1990), "Loss volatility, bankruptcy, and the demand for reinsurance", Journal of Risk and Uncertainty, Vol. 3, No. 3, pp. 221-245. 
16. Hungarian Central Bank (Magyar Nemzeti Bank) (N/A), "Golden Books", available at: https://www.mnb.hu/en/supervision/time-series/golden-books (2 December 2018).

17. Insurance Europe (N/A), "European insurance industry database", Total insurance, available at: https://www.insuranceeurope.eu/insurancedata (5 December 2018).

18. International Association of Insurance Supervisory (N/A), "Insurance Core Principle 1", available at: https://www.iaisweb.org/page/supervisory-material/insurance-coreprinciples//file/77910/all-adopted-icps-updated-november-2018 (5 February 2019).

19. Kim, Y. D., Anderson, D. R., Amburgey, T. L., Hickman, J. C. (1995), "The use of event history analysis to examine insurer insolvencies", Journal of Risk and Insurance, Vol. 62, No. 1, pp. 94-110.

20. Klein, R. W. (2013), „Insurance market regulation: Catastrophe risk, competition, and systemic risk", in Dionne, G. (Ed.), Handbook of insurance, Springer, New York, NY, pp. 909939.

21. Laeven, L., Levine, R. (2009), "Bank governance, regulation and risk taking", Journal of financial economics, Vol. 93, No. 2, pp. 259-275.

22. Pasiouras, F., Gaganis, C. (2013), "Regulations and soundness of insurance firms: International evidence", Journal of Business Research, Vol. 66, No. 5, pp. 632-642.

23. Pi, L., Timme, S. G. (1993), "Corporate control and bank efficiency", Journal of Banking \& Finance, Vol. 17, No. 2-3, pp. 515-530.

24. The Polish Insurance Association (N/A), "Statistics", available at: https://piu.org.pl/en/annual-piu-report/ (10 December 2018).

25. Schaeck, K., Cihák, M. (2014), "Competition, efficiency, and stability in banking", Financial Management, Vol. 43, No. 1, pp. 215-241.

26. Shim, J. (2011), "Mergers \& acquisitions, diversification and performance in the US propertyliability insurance industry", Journal of Financial Services Research, Vol. 39, No. 3, pp. 119 144.

27. Shim, J. (2015), "An investigation of market concentration and financial stability in propertyliability insurance industry", The Journal of Risk and Insurance, Vol. 84. No. 2, pp. 567-597.

28. O'Sullivan, N., Diacon, S. R. (2003), "Board composition and performance in life insurance companies", British Journal of Management, Vol. 14, No. 2, pp. 115-129.

29. Rubio-Misas, M., Fernández-Moreno, M. (2017), "Solvency surveillance and financial crisis: evidence from the Spanish insurance industry", Spanish Journal of Finance and Accounting/Revista Española de Financiación y Contabilidad, Vol. 46, No. 3, pp. 272-297.

30. Shiu, Y. (2004), "Determinants of United Kingdom general insurance company performance", British Actuarial Journal, Vol. 10, No. 5, pp. 1079-1110.

31. Tipurić, D., Pejić Bach, M., Pavić, T. (2008), "Dynamics of Concentration of Insurance Industry in Selected Transition Countries of Central and Eastern Europe", Post-Communist Economies, Vol. 20, No.1, pp. 97-118.

32. Uhde, A., Heimeshoff, U. (2009), "Consolidation in banking and financial stability in Europe: Empirical evidence", Journal of Banking \& Finance, Vol. 33, No. 7, pp. 1299-1311.

33. Weiss, M. A., Choi, B. P. (2008), "State regulation and the structure, conduct, efficiency and performance of US auto insurers", Journal of Banking \& Finance, Vol. 32, No. 1, pp. 134-156.

34. World Bank (N/Aa), "World Bank national accounts data and OECD National Accounts data files", available at:

https://data.worldbank.org/indicator/NY.GDP.PCAP.KD.ZG?locations=HU

(15 December 2018).

35. World Bank (N/Ab), "World Bank national accounts data and OECD National Accounts data files", available at:

https://data.worldbank.org/indicator/NY.GDP.PCAP.KD.ZG?locations=PL (15 December 2018).

36. World Bank (N/AC), "World Bank national accounts data and OECD National Accounts data files", available at: https://data.worldbank.org/indicator/NY.GDP.PCAP.KD.ZG?locations=HR

(15 December 2018). 
37. Yanase, N., Asai, Y., Lai, G. C. (2008), "Organizational Structure and Risk Taking: Evidence from the Life Insurance Industry in Japan", in 12th Annual APRIA Conference, available at https://www.rieb.kobe-U.ac.jp/academic/ra/monetary/2008/mme/asai.pdf

(15 January 2019).

\section{About the authors}

Tomislava Pavić Kramarić, Ph.D. is a senior research associate and a senior lecturer at the University Department of Professional Studies, University of Split. She received her bachelor and master degrees from the Faculty of Economics and Business, University of Zagreb while she received a Ph.D. from the Faculty of Economics, University of Rijeka. She also has 10 years of professional experience in the financial services regulatory authority. Her research interests include corporate finance, financial analysis, and insurance. The author can be contacted at tpavic@oss.unist.hr.

Marko Miletić, Ph.D., is a research associate and a college professor at the University Department of Professional Studies, University of Split. He holds a Ph.D. degree in Finances from Faculty of Economics, Business, and Tourism, University of Split. His field of research focuses on corporate finance, capital budgeting, and taxes. He is also active in publishing his academic research work. The author can be contacted at mamiletic@oss.unist.hr.

Renata Kožul Blaževski, University Specialist of Economics, is a senior lecturer at the University Department of Professional Studies, University of Split. She received her MSC degree from the Faculty of Science, Department of Mathematics, University of Zagreb and her University Specialist of Economics degree from the Faculty of Economics and Business, University of Zagreb. Her research interests include time series analysis and econometrics. The author can be contacted at rkozulb@oss.unist.hr. 


\section{Appendices}

Appendix A

Correlation matrix for Croatian insurance market

\begin{tabular}{|c|c|c|c|c|c|c|c|c|}
\hline & In_size & RE & $\begin{array}{l}\text { claims } \\
\text { growth }\end{array}$ & $\begin{array}{l}\text { gwp_ } \\
\text { growth }\end{array}$ & $\begin{array}{l}\text { prem_ } \\
\text { surplus }\end{array}$ & MS5 & $\begin{array}{l}\text { GWP } \\
\text { in_GDP }\end{array}$ & $\begin{array}{l}\text { GDP } \\
\text { pc_growth }\end{array}$ \\
\hline In_size & 1.0000 & & & & & & & \\
\hline RE & 0.0326 & 1.0000 & & & & & & \\
\hline claims_growth & -0.1720 & -0.0231 & 1.0000 & & & & & \\
\hline GWP_growth & 0.0503 & 0.1021 & 0.0298 & 1.0000 & & & & \\
\hline prem_surplus & 0.1849 & 0.0811 & -0.0737 & -0.0248 & 1.0000 & & & \\
\hline MS5 & -0.0335 & -0.0106 & 0.0150 & -0.8821 & 0.0070 & 1.0000 & & \\
\hline GWP_in_GDP & -0.0565 & -0.1233 & -0.0178 & -0.8305 & 0.0504 & 0.5796 & 1.0000 & \\
\hline GDP_pc_growth & 0.0516 & 0.1234 & 0.0335 & 0.9954 & -0.0260 & -0.8382 & -0.8412 & 1.0000 \\
\hline
\end{tabular}

Source: Authors' work

Appendix $B$

Correlation matrix for Hungarian insurance market

\begin{tabular}{|c|c|c|c|c|c|c|c|c|}
\hline & In_size & RE & $\begin{array}{l}\text { claims } \\
\text { growth }\end{array}$ & $\begin{array}{l}\text { gwp_g } \\
\text { rowth }\end{array}$ & $\begin{array}{l}\text { prem_- } \\
\text { surplus }\end{array}$ & MS5 & $\begin{array}{l}\text { GWP_ } \\
\text { in_GDP }\end{array}$ & $\begin{array}{l}\text { GDP_ } \\
\text { pc_growth }\end{array}$ \\
\hline In_size & 1.0000 & & & & & & & \\
\hline RE & -0.4625 & 1.0000 & & & & & & \\
\hline claims_growth & 0.0169 & -0.2011 & 1.0000 & & & & & \\
\hline GWP_growth & -0.1708 & -0.0166 & 0.2368 & 1.0000 & & & & \\
\hline prem_surplus & 0.5353 & -0.4694 & 0.0610 & 0.0223 & 1.0000 & & & \\
\hline MS5 & 0.0203 & 0.0068 & -0.1243 & -0.0326 & -0.0456 & 1.0000 & & \\
\hline GWP_in_GDP & -0.0148 & -0.0078 & 0.0380 & 0.0128 & 0.0258 & -0.7384 & 1.0000 & \\
\hline GDP pc growth & 0.0130 & 0.0511 & -0.1116 & -0.0420 & 0.0039 & 0.1443 & -0.3952 & 1.0000 \\
\hline
\end{tabular}

Source: Authors' work

Appendix C

Correlation matrix for Polish insurance market

\begin{tabular}{|c|c|c|c|c|c|c|c|c|}
\hline & In_size & RE & $\begin{array}{l}\text { claims } \\
\text { growth }\end{array}$ & $\begin{array}{l}\text { gwp } \\
\text { growth }\end{array}$ & $\begin{array}{l}\text { prem_ } \\
\text { surplus }\end{array}$ & MS5 & $\begin{array}{l}\text { GWP } \\
\text { in_GDP }\end{array}$ & $\begin{array}{l}\text { GDP_ } \\
\text { pc_growth }\end{array}$ \\
\hline In_size & 1.0000 & & & & & & & \\
\hline RE & -0.1959 & 1.0000 & & & & & & \\
\hline claims_growth & 0.0559 & -0.0432 & 1.0000 & & & & & \\
\hline GWP_growth & -0.0823 & 0.0469 & 0.0254 & 1.0000 & & & & \\
\hline prem_surplus & -0.0378 & -0.0961 & 0.0151 & 0.0291 & 1.0000 & & & \\
\hline MS5 & 0.0558 & 0.0440 & 0.0528 & 0.0375 & -0.0281 & 1.0000 & & \\
\hline GWP_in_GDP & -0.0011 & 0.0291 & 0.1185 & -0.0192 & 0.1459 & 0.5063 & 1.0000 & \\
\hline GDP_pc_growth & 0.0161 & 0.0343 & 0.1057 & 0.0065 & 0.0983 & 0.7435 & 0.8492 & 1.0000 \\
\hline
\end{tabular}

Source: Authors' work 
Appendix D

Fisher-type unit-root test for Croatian insurance market

\begin{tabular}{lcccc}
\hline Variable & $\begin{array}{c}\text { Inverse chi-squared } \\
\text { p-value }\end{array}$ & $\begin{array}{c}\text { Inverse normal } \\
\text { p-value }\end{array}$ & $\begin{array}{c}\text { Inverse logit } \\
\text { p-value }\end{array}$ & $\begin{array}{c}\text { Modified inverse } \\
\text { chi-squared p-value }\end{array}$ \\
\hline InZ & 0.0000 & 0.0086 & 0.0000 & 0.0000 \\
In_size & 0.0000 & 0.0741 & 0.0254 & 0.0000 \\
RE & 0.9846 & 0.9999 & 1.0000 & 0.9696 \\
claims_growth & 0.0000 & 0.0321 & 0.0000 & 0.0000 \\
gwp_growth & - & - & - & - \\
prem_surplus & 0.0000 & 0.0070 & 0.0000 & 0.0000 \\
MS5 & - & - & - & - \\
GWP_in_GDP & - & - & - & - \\
GDP_pc_growth & 1.0000 & 0.9996 & 0.9986 & 0.9995 \\
\hline SOUFe:AuthOrs' & & & & \\
\hline
\end{tabular}

Source: Authors' work

Appendix $E$

Fisher-type unit-root test for Hungarian insurance market

\begin{tabular}{lcccc}
\hline Variable & $\begin{array}{c}\text { Inverse chi-squared } \\
\text { p-value }\end{array}$ & $\begin{array}{c}\text { Inverse normal } \\
\text { p-value }\end{array}$ & $\begin{array}{c}\text { Inverse logit } \\
\text { p-value }\end{array}$ & $\begin{array}{c}\text { Modified inverse } \\
\text { chi-squared } \text {-v-value }\end{array}$ \\
\hline InZ & 0.6131 & 0.9713 & 0.9908 & 0.6368 \\
In_size & 0.9967 & 0.9987 & 0.9989 & 0.9883 \\
RE & 0.0000 & 0.0091 & 0.0000 & 0.0000 \\
claims_growth & 0.0000 & 0.0000 & 0.0000 & 0.0000 \\
gwp_growth & 0.0000 & 0.0099 & 0.0000 & 0.0000 \\
prem_surplus & 0.0000 & 0.0000 & 0.0000 & 0.0000 \\
MS5 & - & - & - & - \\
GWP_in_GDP & 0.0000 & 0.0000 & 0.0000 & 0.0000 \\
GDP_pc_growth & 0.0000 & 0.0000 & 0.0000 & 0.0000 \\
\hline
\end{tabular}

Source: Authors' work

Appendix $F$

Fisher-type unit-root test for Polish insurance market

\begin{tabular}{lcccc}
\hline Variable & $\begin{array}{c}\text { Inverse chi-squared } \\
\text { p-value }\end{array}$ & $\begin{array}{c}\text { Inverse normal } \\
\text { p-value }\end{array}$ & $\begin{array}{c}\text { Inverse logit } \\
\text { p-value }\end{array}$ & $\begin{array}{c}\text { Modified inverse } \\
\text { chi-squared p-value }\end{array}$ \\
\hline InZ & 0.0000 & 0.0000 & 0.0000 & 0.0000 \\
In_size & 0.0000 & 0.0023 & 0.0000 & 0.0000 \\
RE & 0.0000 & 0.0291 & 0.0000 & 0.0000 \\
claims_growth & 0.0000 & 0.0000 & 0.0000 & 0.0000 \\
gwp_growth & 0.0000 & 0.0099 & 0.0000 & 0.0000 \\
prem_surplus & 0.0000 & 0.0000 & 0.0000 & 0.0000 \\
MS5 & 1.0000 & 1.0000 & 1.0000 & 1.0000 \\
GWP_in_GDP & 0.0000 & 0.0000 & 0.0000 & 0.0000 \\
GDP_pc_growth & - & - & - & - \\
\hline
\end{tabular}

Source: Authors' work 